\title{
Citizen Participation and Engagement in Urban Governance: Perception of Finnish and Polish Local Officials $^{1}$
}

Katarzyna Radzik-Maruszak ${ }^{2}$, Michaela Bátorová ${ }^{3}$

\begin{abstract}
Participation has recently received renewed attention in the context of governance. This is especially relevant in countries where democratization and decentralization have led to an increased promotion of citizen involvement into the decision-making process. This article suggests that the current debate on civic engagement would benefit from further reflection on how the concept of participation is implemented in contexts, particularly in the Nordic as well as Central and Eastern European countries, where ideas of local democracy, urban governance and involvement can be understood differently. By exploring citizen participation from the perspective of local officials in two European cities - Lublin, Poland and Tampere, Finland, the article seeks to add significant data to the on-going scholarly discussion. Based on qualitative research, it examines advantages and disadvantages of the provisions of the local citizen-participation frameworks, as perceived by the officials of the selected case cities. In the conclusion, the authors point out that although both cities have different democratic institutional systems as well as commonly accepted notions of citizen participation, their city halls frequently face similar problems related to the use of participatory tools.
\end{abstract}

1 The article was written within a project PRVOUK P17 Sciences on society, politics and the media in contemporary challenge, at Charles University in Prague, Faculty of Social Sciences, Institute of Political Studies.

2 Assistant Professor at the Faculty of Political Science, Maria Curie-Skłodowska University, Lublin, Poland, Plac Litewski 3, 20-080 Lublin, Poland and Postdoctoral fellow in Institute of Political Studies, Faculty of Social Science, Charles University in Prague, U kř́že 8, 15800, Prague, Czech Republic.

3 University lecturer and researcher at the School of Management, Department of Regional Studies, University of Tampere, Tampere, Finland; Kalevantie 4, 33014 Tampereenyliopisto, Finland. 
Key words: local self-government, pros and cons of citizen participation, democracy, governance

\section{Introduction}

Since the 1980s, extensive changes have occurred in European local self-governments. They have been related to the concept of New Public Management (NPM), which resulted in the shift from traditionally understood local government to local governance, with increasing requests for a wider participation of various stakeholders in the society - mainly citizens, NGOs and private companies. A number of participative tools have been introduced into the daily work of many local-government bureaucracies in Europe. However, the implementation and further usage of these tools have not always been met only with a positive reception.

The aim of this article is to outline two approaches to implementing participative democracy tools within the traditional models of representative democracy. Our main research object is the institutional framework applied in two different cities guiding said implementation process. We study this framework on the basis of secondary sources (strategic city documents, reports, official city-webpages, etc.). This allows us to critically clarify the formal discourse about the citizen participation in the cities under discussion. At the same time, we are interested in finding out how civil servants - the carriers of the implementation activities - perceive the functionality of this framework and what they perceive as pro and contra in these frameworks. We study their opinions via interviews with semi-structured and open-ended questions. Our case cities are the city of Tampere in Finland and the city of Lublin in Poland.

In the first section of the article, by elaborating on the theoretical concepts of urban governance and citizen participation, we aim to clarify how current scholarship understands the advantages and disadvantages of citizen involvement in municipal decision-making processes. In the second section of the paper, based on the analysis of official documents, we focus on the context and practices of the applied framework of citizen participation in the cities in question. This framework is later juxtaposed with the local officials' perceptions about the pros and consof involving the citizens into decision-making processes. The paper concludes that although both cities provide different types of participatory tools, civil servants quite often face similar problems and have parallel attitudes related to the outcomes yielded by these tools. 


\section{The basic notions: urban governance, citizen participation and engagement...}

In the last twenty-five years, a special role in the debate over local government, its developments and reforms, has been played by the concept of governance (Rhodes 1997; John 2001; Bevir 2009; Levi-Faur 2012). The transformation from traditionally understood government to governance was first witnessed in Anglo-Saxon countries and later - to a greater or lesser extent - in other Western European states (John 2001). In recent years the practical implementation of the concept has, however, also been visible in Central and Eastern Europe. ${ }^{4}$ Nevertheless, governance is a kind of buzzword that is difficult to explain, its main assumption amounts to the idea that neither the state nor any other actors of public life have a monopoly on the truth, material and financial resources, information, knowledge or even coercive measures (Pawłowska 2007, 162). Instead, the power is distributed geographically and socially, between many levels and stakeholders. This has brought many consequences and implications both for the governing process as such as for the stakeholders that are involved into it. In this context at least two issues should be noted.

First, the transformation from government to governance chiefly means that the state has moved from the position where it both controlled and acted to a situation where it steers the boat while non-state actors do the rowing (Osborne and Gaebler 1993; McLaverty 2011, 402). Such steering activities are important especially due to the complexity of the challenges communities face. And since the societal actors have important resources for helping to solve these complex problems, they need to be involved in the policy-making process (Klijn 2008). In line with this, other scholars describe the shift to governance not only as changing the activities of the state but also reducing the role the government plays within the society. Therefore, governance at the local level can be understood as committing the elected government and officials to work with others from outside city hall and further formal and informal networks and partnerships of various kinds (Radzik-Maruszak and Mieczkowska-Czerniak 2013; McLaverty 2011; Rhodes 1997).

Second, as respected authors Torfing, Peters, Pierre, and Sørensen (2012) point out, the idea of (interactive) governance notably changes the roles played by politicians, administrators and citizens. The first group cannot solely be seen as sovereign political decision-makers who rule by passing laws; they must also take on the position of those who create, monitor and control the practice of governing. Administrators not only have to be bureaucrats who implement the law but also a group that takes care of effectiveness, the flexibility of the process in question and the atmosphere of sustained dialogue. Hence, in this context, they should act

4 In this context it should be noted, however, that some researchers call into question the possibility of the actual implementation of the governance paradigm in non-Anglo-Saxon countries, and even more in states that have recently undergone political system transformation (Stoker 2011, Pawłowska 2007). 
rather as managers of interaction (Torfing et al. 2012, 156). Finally, citizens should not be perceived only as voters and subjects of politics between elections but also as a group that has a legitimate, institutionalized right to have a say in governance. Therefore, citizen involvement is no longer seen merely as a way to ensure citizens' democratic influence but rather as a means of enhancing the efficiency and effectiveness of public governance by tapping into the experiences, demands, and ideas of different user groups (160).

We believe that the complexity of governance is even more reflected in the cities. The urban environment is complicated by the number of stakeholders involved in the governing process, frequent politicization and the presence of contradictory interests. Therefore, direct and intensive interactions between local governments and citizens as well as collaborative decision-making and planning should be considered to be key issues. In reality, however, citizen participation constitutes a complex matter.

On the one hand, many arguments in favour of broadening citizen involvement into the governing process can be found. First, their participation significantly increases its legitimacy and undoubtedly promotes and fosters accountability and the transparency of the process. In addition to that, with regard to the context of the post-Soviet Bloc countries, extended participation is often connected with a democratization of the governing process. Second, citizen involvement also plays an educational function; it affects the level of interest in local affairs and encourages civic skills and virtues. Third, closer cooperation between politicians, administrators and citizens, especially at the grass roots level, significantly narrows the gap that arose between these groups (Flinders and Moon 2011, 661). Fourth, the experience of many local governments indicates that citizen involvement considerably increases the efficiency and effectiveness of governing; if people are consulted in the early stage of decision-making, they are less likely to express their opposition and dissatisfaction afterwards. Moreover, in accordance with governance theory, citizens are seen as co-partners, and therefore they cannot blame other stakeholders for possible failures. Some scholars also argue that the citizen involvement is intended to produce better decisions, and thus professionalization benefits the rest of society (Irvin and Stansbury 2004, 56). Finally, new forms of civic engagement, often linked to participatory and deliberative democracy, can be perceived as an answer to the weaknesses of traditional, representative democracy, and in particular to the increasing decline in voter turnout and little interest in local issues on the part of the local population.

On the other hand, citizens' deeper involvement also brings many challenges, both for stakeholders and the whole governing process. First, politicians and administrators have to abandon their routines as well as their long-established procedures and introduce policies that are based on citizens' engagement and mutual trust. Therefore, initiatives undertaken by citizens cannot be perceived as an obstruction 
but rather as a new policy-making tool (Radzik-Maruszak and Mieczkowska-Czerniak 2013). Second, citizens are not equally interested in deeper involvement or not have enough knowledge to take rational and general well-being-focused decisions. Some authors even point out that an increase in political activity among the lower socio-economic classes could lead to more authoritarian ideas and, in consequence, to a decline in the consensus on the basic norms of democracy (Dahl 1956, 89; Sartori 1987). Third, when accepting the role of partners of local authorities, local communities have to understand and assume a higher level of responsibility. In many democracies, especially the new ones, this can constitute a problem, though. Fourth, a more complex, messy and asymmetrical patchwork of relations between the local government and other actors may result in tensions, e.g. between elected representatives and those who participate directly. Moreover, the broader inclusion of citizens into decision-making significantly prolongs and complicates the process as such. Finally, as Airaksinen and Haveri indicate, when the number of cooperative actors involved in implementation increases, and the number of decisions requiring collective action grows, the prospect of a collective solution declines (Airaksinen and Haveri 2012, 303). Therefore, it can be expected that attitudes of some decision makers to applying a greater collective decision-making process might be perceived as quite negative. From the perspective of the theory of bounded rationality (Simon 1997), claiming that human cognition is limited and people are able to make decisions only with a limited amount of information, such negative attitudes have a certain justification. To avoid the risk of sinking into the ocean of individual interests, needs and requests, which could lead to the "paralysis by analysis", it is easier to work with more general, average-value, or simplified data, which, expectedly, would satisfy the majority of affected participants.

How all these challenges are perceived by civil servants, the carriers and implementers of participative tools, who channel the requests between decisionmakers (elected politicians) and citizens, is still not very well documented. In our comparative article, we aim to bring considerable empirical insight into this topic with examples from Finland and Poland.

\section{Data and methods}

We have undertaken and built the comparative analysis of empirical data collected from two cities, Tampere (Finland) and Lublin (Poland). The case-study selection was dictated by at least two groups of reasons. On the one hand, Tampere and Lublin are rather similar in size, and, as mentioned before, in their countries they play the role of pioneers in implementing innovative reforms allowing citizens wider participation. In the case of Tampere, the city is even perceived as a leader in publicsector innovation that tries to link efficient service provision with active resident engagement. In turn, Lublin in Poland is seen as a city in transition that is not afraid to introduce complex participatory practises in a fast way. Moreover, with regard to 
administrative structure both cities decided to create special units responsible for civic participation. On the other hand, however, Tampere and Lublin come from different local-government traditions (Denters and Rose 2005; Loughlin et al. 2010) and therefore are quite distinct in institutional arrangements and the stage of urban governance. The differences are also visible in the level of citizen participation and their interest in local issues (Table 1 and Table 2); this makes the comparison even more interesting.

Traditionally, Finnish local governments are highly service-oriented units operating in the framework of a strong representative democracy. Their main role is to take care of the well-being of their citizens by assuring the equal provision of welfare services through very strong professional administration. With the arrival of the New Public Management (NPM) ideas (in the late 80s, see Bátorová 2012), the importance of this professional role increased even more, but local governments also started to be active in involving community actors (mainly private companies) in the policy-making process. In this way, the municipal officials could foster principles of market mechanism and/or gain more information about the consumers'/customers' satisfaction with the provided services (Klijn 2008; Häikiö 2010).

Despite its well-meant attempts, the Finnish local-government system can still be criticized for its (participative) democratic deficit. First, the traditional organizational structure following the "council-manager model" of local government (Mouritzen and Svara 2002) collides with the democratic accountability due to the limited formal powers of leading politicians ${ }^{5}$ in the decision-making process. Second, the strong application of NPM practices emphasizing hierarchical mechanisms of power control within the organization are not supportive enough for the horizontal mechanisms of power-sharing needed for emerging governance networks among the external organizations and citizens (Klijn 2008). Following the example from the city of Tampere, we try to demonstrate how these challenges related to the lack of participative democracy can be tackled by implementing various participative tools in the municipal institutional framework.

In the early 1990s, a democratic change began in Central and Eastern European countries. The then introduced reforms can be divided into at least three groups. The first one aimed to rebuild a strong local government that would be independent of central authority; that operation was based on the rule of law. In this context, local authorities were strongly believed to be an antidote to the centralized state and strived to become an institution through which people could gain control over their lives, as well as regenerating and revitalizing their communities (Campbell and Coulson 2006, 543). The second group of reforms, undoubtedly inspired by

5 In the council-manager model, leading civil servants are traditionally more powerful than the democratically elected political leaders. In comparison to the strong-mayor form of governments (Mouritzen and Svara 2002) - especially in contrast with directly elected mayors, this situation gives the impression that civil servants are not directly accountable to citizens, since they cannot be punished for mal-policies by not obtaining citizens' votes in the elections. 
the concept of New Public Management, put more emphasis on the efficiency and effectiveness of local governments' operation as well as on efficient service provision. In many cases, however, the implementation of those caused tension between newly established rules of law and the principles of NPM. Finally, in many countries recent years have brought a marked interest in the paradigm of governance and the broader inclusion of various stakeholders into the decision-making process (Loughlin et al. 2010).

In comparison to Finland, the local-government reforms carried out in Poland should be distinguished due to several issues. Firstly, the changes were implemented in a relatively short time and met a high degree of social acceptance. Against the background of the three other major reforms carried out in the 1990s - health, education and pension systems - the local-government reform was prepared and implemented well and therefore positively evaluated by society (OBOP 1999). Secondly, de facto since the beginning the principles of democracy were supplemented by the values of efficiency and effectiveness. In this context, the territorial reform constitutes a good example; in contrast to Hungary, the Czech Republic and Slovakia, large territorial units, akin to the Northern type of local government, were created. As a result, the municipalities, counties and regions in question were able to offer a wide package of local services. Thirdly, with regard to the implemented changes, Poland took inspiration from Western Europe. This meant inter alia a focus on stronger leadership (Piasecki 2006) as well as on the new ways of citizen involvement into the decision-making process. As far as the latter issue is concerned, the city of Lublin constitutes a good example.

In the present paper, we used two main sets of data. First, the data from various official documents (strategy documents, activity reports, etc.) and official web pages of both cities were used. We focused on the ways how citizens were perceived/named in those documents, whether as governmental partners or just as customers or consumers of public services. This enabled us to outline the official discourse about the citizen participation used in both cities. The analysis of official data also enabled us to describe the participative framework applied in both cities. Second, to map local officials' perception on citizen involvement a qualitative data collection was executed. Six in-depth, semi-structured interviews were conducted in September 2013 (Tampere, Lublin) and December 2014 (Lublin) with leading department officers from city halls in Tampere and Lublin. In both cities the interviews with the heads of external relations, namely, the Department of Cooperation with NGOs and Social Participation in Lublin, and the Local Democracy Unit in Tampere, and two other officers from city office were conducted. During the interviews, we asked open questions referring to the institutional framework introduced in particular cities and the advantages and disadvantages of citizen participations from the local officers' perspective. The intention was to create a space for respondents to reflect on their own experience with and attitudes to the applied participatory framework. 


\section{The context and practice of citizen participation in Tampere}

The selection of Tampere ${ }^{6}$ as a case study is due to its leadership position in publicsector innovativeness. Among other activities, Tampere is the first city in Finland which decided to be actively innovative with its governmental model, trying to interlink a higher responsiveness of the provided public services with a democratic legitimacy of the made decisions. In Finland this innovative governmental model was labelled "The Tampere model".

The "Tampere model" is based on a combination of principles typical of the New Public Management tools (an emphasis on economic efficiency, as viewed by Rhodes 1996) and governance (fostering participative democracy). It focuses on the re-organization of both the internal structures and the external interaction with its environment. In summary, this model aims to improve citizen involvement in the municipal decision-making process while keeping the quality, efficiency and effectiveness of provided public services on a high level (City of Tampere 2007, 2014). In general it should be noted, however, that the level of involvement and interest in city affairs among Tampere residents is relatively high (Table 1).

The "Tampere model" consists of three parts: 1) the mayoral model, 2) the purchaser-provider model, 3) the civic-participation model (Figure 1).

\section{Table 1}

Voter turnout to the Tampere city council

\begin{tabular}{|c|c|}
\hline Election year & Turnout in \% \\
\hline 2004 & 55.7 \\
\hline 2008 & 59.4 \\
\hline 2012 & 56.3 \\
\hline
\end{tabular}

Source: Statistic Finland: http://www.stat.fi/index_en.html (accessed 12 May 2015).

The "Mayoral model" (number 1 in Figure 1) is one of the most significant (and newest) structural changes supporting greater, yet indirect, involvement of citizens in political decision-making. In the traditionally very strong managementoriented (or technocratic) municipal organization (Haveri et al. 2009), this new mayoral model aims to improve the influence of political leadership. For traditional Finnish local governments, it is common that the municipality is informally led by an appointed (not an elected) civil servant - the city manager (or CEO). The political leaders hold only a part-time or a hobby (as some professionals dare to

6 The City of Tampere is a medium-size city (more than 220,000 inhabitants in 2014) situated in Central-Southern Finland. It is a former industrial city with a wide regional significance - the second most important after the capital region of Helsinki. 
call it) leadership position, while the leading civil servants usually have all the competences for performing both political and administrative duties ${ }^{7}$ (Sandberg 2004). However, since these civil servants are not democratically elected (only appointed by the council), they are not directly accountable to the citizens. Thus, citizens have less access to influencing who leads their city and how, which is against the trend of fostering the principles of direct or participative democracy.

\section{Figure 1}

Simplified version of the Tampere operational and organization model with added focus on the information flow from/to the citizens' participation tools

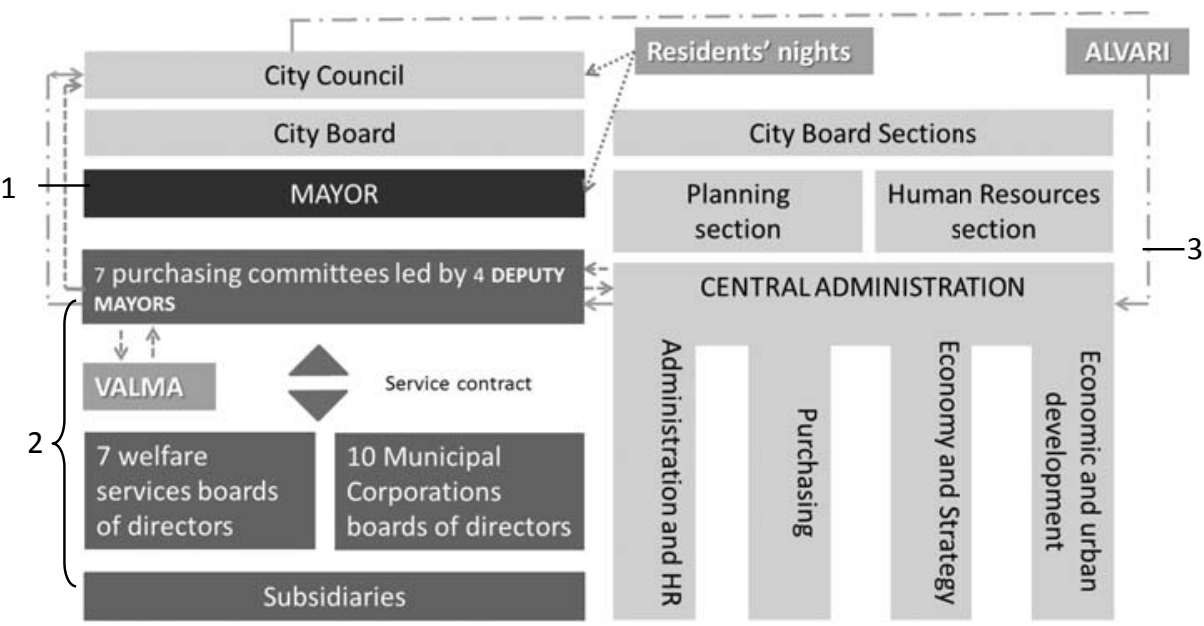

With the "Mayoral model" of local leadership, established in the year 2007, Tampere seeks to remedy this democratic deficit. This new model enables the city council $^{8}$ to elect from among their members a (full-time) political leader responsible for co-ordinating both the administrative and the political tasks and thus to empower the political influence in the city management. At the same time, it provides greater means for hearing the citizens' voice, though by now executed only indirectly via the elected local representatives. ${ }^{9}$

The Tampere model enables citizens' indirect participation also via city-management channels. One of such managerial channels is the purchaser-provider cooperation model of service delivery (referring to number 2 in Figure 1); for more

7 They have specialized education, and usually they are members of some political party that in most of the occasions enjoys the majority in the pluralistic municipal council (Sandberg 2004).

8 The City council is comprised of 67 directly elected councillors, elected based on the principle of proportional representation.

9 According to the new city strategy (published in the year 2014), the city of Tampere is planning to proceed with the implementation of a directly elected mayor (City of Tampere 2014). 
details see City of Tampere 2007. This model is expected to assure more variety, effectiveness and economy in the service provision by involving more private companies in providing public services. In addition, and for the purpose of our paper perhaps more importantly, this model is expected to ensure that residents are heard as users of services, especially during the process of planning services (City of Tampere 2014). The purchaser-provider model is organized in a customer-oriented way, which means that "residents are a crucial co-operation partner for service planning. Customer feedback is systematically collected and new means of participating and influencing are actively developed" (City of Tampere 2014, 4). In addition, this model provides another democratic feature. It allows elected politicians to have greater influence on the selection of public servicers and service providers, which were the activities traditionally in the hands of the professional civil servants. This purchaser-provider model aims to empower the political influence of elected representatives in municipal development.

While these two reforms empowered citizen participation only indirectly, by empowering their elected representatives, according to the official webpage of the city of Tampere (City of Tampere 2014), there are at least another five ways in which citizens can be directly involved in the municipal decision-making process. These tools (referring to number 3 in Figure 1 and representing the third component of the Tampere model) are administered by the Tampere Local Democracy Unit, which is similar to Lublin's Department of Cooperation with NGOs and Social Participation. Due to the space limitation, we will focus on the presentation of the three most crucial participative tools ${ }^{10}$ in our opinion: the web-based forum, neighbourhood workgroups and residents' nights.

\section{Web-based forum}

The Internet-based platform called Valma was established in the year 2003 for collecting citizen feedback about planned policy proposals. The practice on this online platform is rather simple: the page administrators (civil servants) upload a policy proposal and in a specific online forum citizens react to it within the allocated time. Citizens' opinions are directly sent back to the city personnel and to local politicians (deputy mayors, heads of the committees and all other members of the respected committees) who work on the policy proposal. In this way, citizens can see what the city management is planning to do, and at the same time they have a chance to express their opinions and provide their own perspectives on the policy under scrutiny (Valma forum 2013). The usage of this tool by citizens depends very much on the discussed policy. For example, in year 2012, citizens could express their opinions on 14 policy proposals, dealing with social and health services, culture, parks

10 The two other tools are Youth parliament and Children's parliament. In the long-term perspective these two tools of participatory democracy might have even greater influence on improving the citizenship in Tampere, since they teach small children and young adults how to be active agents in their communities. 
and green spaces, education and training, streets and traffic, zoning and construction, and other issues (Valma forum 2013). Although the quantity of citizen input might not be very high (in average only some 19 comments per proposal), as one of the interviewed local officers mentioned, more important than the amount of comments is the quality of comments which bring new knowledge or perspectives to the policy-preparation process (Officer 2, 2013, Tampere).

\section{Neighbourhood workgroups}

Another tool allowing citizen engagement in policy preparation is activities of the "Alvari local workgroups". Alvari started as a citizen initiative already in the year 2002, together with the new management model. In the year 2007 Alvari was accepted as an official tool for direct civic participation in municipal decisionmaking. These workgroups consist of residents and NGOs from four Tampere districts/neighbourhoods, and together - in a more coordinated or consolidated way, compared to the Valma platform - they participate in service planning (mainly services which directly affect their district) by commenting on the issues under preparation. Citizens may also introduce their own initiatives, if they consider them important for local residents. Based on the information from Alvari's website (which is also an integrated page of the official city of Tampere webpage), by the year 2011 the work groups were involved in more than 350 procedures. They have been dealing with issues related to library services, public transport, health care, home care for the elderly, schools, parks, day care, youth facilities, etc. They also actively participated in the process of municipal budget preparation and in service networks. They implemented several initiatives, including practical steps which resulted, among other things, in establishing a health kioski and village-hall activities (Alvari 2011, Tampereenkaupunki: kuntademokratiayksikki 2011).

Group meetings take place altogether over 100 times a year, and in the year 2011 there were some 256 full members involved in all four regional Alvari workgroups (Tampereenkaupunki: kuntademokratiayksikkö 2011), together with yet another 4500 non-member participants (as noted by the interviewed Officer 2, 2013, Tampere). The admission of new Alavari members occurs every other year. The membership is formally authorized by the Executive Board of the Tampere City Council. This ceremonial procedure is performed to show how important and binding Alvari's opinions are for the local politicians. Despite the existence of the membership, the Alvari meetings are open to everybody, and everybody's voice has the same relevance (as mentioned by the interviewed Alvari city officer, 2013).

\section{Residents' nights}

Another officially organized activity supporting citizen participation are the "residents' nights". These evening events constitute a part of Alvari's activities and are organized by the Management centre (HALO) and coordinated by the Local De- 
mocracy Unit (Kuntademokratiayksikkö) of the City of Tampere. Meetings are led by the Mayor and the deputy mayors. The head of the municipal council and representatives of the political parties also participate. While the Valma online-based forum and Alvari's meetings enable citizens to express their opinions and suggestions for policy improvements in the bottom-up direction (although these policy-proposals are provided from the "top"), the "residents' nights" provide a platform for a twoway direct interaction between citizens and elected officials. On the one hand, the Mayor and all other politicians and leading civil servants have a chance to directly hear citizens' problems and issues; on the other hand, they have a chance to explain their reasons for certain municipal proposals. Thus, these evenings should serve not only as citizen's "Speakers' corner", but also as a contribution to the transparency and openness in the municipal decision-making. As Nurminen (2012) mentions, residents' nights encourage the creation of a stronger community life and intensify co-operation between citizens themselves. Meetings are organized sequentially in each of Tampere's 5 districts once a year.

The residents' nights were established in the year 2011. Before, the municipal council (since 2005) and the Mayor (since 2007) used to organize separate meetings with citizens. These gatherings enjoyed a higher frequency during the year; however, as the city-requested analyses showed, they were not effective enough (Nurminen 2012). Therefore, the city council decided to decrease the number of separate meetings and instead to organize 3-5 combined meetings per year so as to avoid duplication of discussed issues, as well as to increase the number of participating citizens and to improve the general quality of citizens' interaction with local authorities (ibid.). Based on Nurminen's report $(2012,8)$, between the years 2005 and 2010 on average 60 citizens participated in a meeting, either with the council or with the Mayor. When the combined "residents' nights" started in 2011, the average participation per meeting increased to 72 . So during the relatively short existence of this new model, the goal of intensifying citizen participation has been undoubtedly achieved.

To sum it up, the analysis of the secondary documents leads us to arrive at the following conclusions: most of the studied public documents treat citizens as residents, consumers, customers, service users or clients (for a further discussion, see Häikiö 2010), which are terms emphasizing individualism, individual values and individual choices. Second, all three participatory tools for citizens are managed by the city administration, and the city officials seem to work as "managers of interaction" between elected officials and citizens, a role described by Torfing et al. (2012) in their book Interactive Governance: Advancing the Paradigm. This also means that officially, based on the provided institutional framework, citizens can influence the political decision-making still rather indirectly, while the influence of city administrators - the municipal professionals, is still quite significant in shaping the final municipal decisions. 


\section{The Tampere model from the civil servants' point of view}

The conducted interviews showed that many civil servants still do not have entirely positive attitudes towards citizen participation as a tool for improving the performance of local governance. Some civil servants are very critical mainly of the lack of citizens' vocational knowledge or too utopian demands (coming from all the participative tools), often promoting only individual interests. One interviewed Alvari officer (2013) also mentioned that problems with citizen participation are caused by the difficult behaviour of some Alvari members, as well as the lack of many social groups participating in Alvari meetings. The interviewee continues:

... most of the members are older people since only they have time to participate in the evening meetings. The middle-aged people with young kids can hardly find time to come in the evening to those happenings. My group is a very good one, because people respect each other, listen to each other and it is easy to make notes from such productive meetings. But in some other groups, there are often some citizens who just criticize everything and never provide relevant solutions.

(Officer 3, 2013, Tampere).

Despite some negative attitudes existing among some civil servants, which the Local Democracy Unit actively tries to minimize by providing professional guidance and consultancy to city employees (Officer 2, 2013, Tampere), the interviewed civil servants also expressed an awareness of a need to have more tools for civic participation. These tools should be more open to new ideas, new problem solutions, and they should follow "the working together" approach more. This is also because these interviewees believe that society has grown up, that there are more highly educated people in the society than ever before, thus civil servants and elected politicians are continually losing the unique power position possessing the most appropriate knowledge and expertise for managing the municipality alone. The position that "the citizens are not stupid" has been expressed during the interviews several times, which is a positive sign for municipal willingness to share the decision-making with a wider population. Thus, as all the respondents confirmed that if citizens are involved in the preparation of policy-proposals early enough, they are able also to accept more easily and better negative decisions - if all the reasons for making those decisions are explained to them clearly enough.

At the same time, however, the Tampere interviewees still believe that keeping the traditional representative-democracy model, which is only complemented (and not supplemented) by the means of participative democracy, is a good idea. This is mainly because:

Somebody must be a leader. Otherwise, there would be chaos.

(Officer 3, 2013, Tampere) 


\section{Lessons drawn from the Tampere case}

The presentation of this reasonable number of ways of attempting to improve the citizen involvement in the municipal decision-making process can teach us several important facts about the character of the participative-democracy framework applied in the Tampere model of local governance. First, although the city of Tampere is facilitating various instruments for direct civic participation, these instruments or means are perceived only as complements to the main governmental form, which is representative democracy. In this way, it seems that the Tampere administration tries to overcome the problems of democratic accountability, which is often unclear in horizontal governance (Klijn 2008), although it might not be so much in accordance with the ideal situation requested by the supporters of participatory democracy.

One could also search in the past for reasons explaining why there is only a limited number of citizens' participative means. As Häikiö (2007) and some interviewed civil servants concluded, the late 1990s saw the first wave of citizen participation. However, the inflow of information from citizens was quite intense and diffused and often did not yield the expected results. The deliberation process took too long, and some decisions were not even reached at all. Having learnt from these experiences of "governance failure" (Jessop 2013), one could state that nowadays the city of Tampere has decided to choose more controlled, organized and coordinated information channels to assure that the citizens' voice is heard as well as to keep the decision-making processes more efficient and effective. Such attitudes can also be seen with regard to the principles of meta-governance, as described, e.g., by Jessop (2013).

In conclusion, from the perspective of the citizen participation or direct democracy, the Tampere model cannot be treated as the ideal case. In addition, the civil servants' do not always show the most positive attitudes towards the participative system, and the respondents believe that more work needs to be done in order to satisfy both the citizens and the performance of the municipal office.

\section{The context and practice of citizen participation in Lublin}

When the communist regime collapsed in Poland in 1989, a significant effort was made to re-build free, independent and directly elected local government. The support for the idea of self-government was clearly shared by the society. In many cases, the reinstatement of local government and the appointment of elected local authorities were perceived as values in themselves (Swianiewicz 2002, 53).

Importantly, the democratization and decentralization processes as well as the establishment of local self-government with elected authorities opened new possibilities for participation. On each level of local government, elected councils were 
introduced. ${ }^{11}$ The significant step in the broadening of participatory mechanisms was also the passing of the Act of 11 October 1991 on Local Referendum (changed in 2000, amended in 2005). In addition, the year 2002 brought an important institutional reform at the municipal level. Up to that year all Polish mayors were appointed by the council and chaired collective executive boards. Since the reform was implemented they have been directly elected, and therefore their position in relation to the council has been significantly strengthened. Some scholars indicate, however, that still they are a bit weaker than in a typical "strong mayor" form, as described by Mouritzen and Svara (2002; for details, see, e.g., Swianiewicz et al. 2006, 115). Finally, other mechanisms broadening citizen involvement were introduced, e.g., local consultations.

However, from a different perspective, it is also true that only some local governments are really interested in engaging in a closer dialogue with citizens. As Swianiewicz points out, there are examples of innovative authorities which try to experiment with wider citizen participation, but most typically, local governments regard participation as a one-way street, that is, they communicate their policies and decisions to their citizens rather than being attentive to bottom-up initiatives and opinions (Swianiewicz 2011, 498). Therefore, we decided to choose Lublin as a case study as its authorities try to be innovative and experiment with modern participatory tools.

Lublin is the capital of the Lubelskie Region with approximately 343,000 registered residents. The city is the ninth largest urban agglomeration in Poland in terms of population. It occupies an area of 140 square $\mathrm{km}$ and is the major urban municipality east of the Vistula River. Lublin is also known as a scientific research centre. In the city there are about 140,000 young people studying at various educational institutions. There are 14 universities and colleges, including the Catholic University of Lublin (KUL), the University of Maria Skłodowska Curie (UMCS), Lublin University of Technology, the Agricultural University of Lublin, as well as the Medical University of Lublin. The City authorities try to cooperate with these academic centres and many innovative ideas, including those related to the involvement of the residents into the decision-making process, come from the universities.

As in other parts of the country, a democratic local self-government was reactivated in the city in the year 1990. At present, Lublin is managed by the 31 -member council and the mayor. The mayor is directly elected. He/she is supported by four deputies responsible for different areas of city management. The deputies are not directly elected but appointed to the position by the mayor (Figure 2). In addition, Lublin is divided into 27 districts/neighbourhoods. Each of them has its own directly elected council, which acts as the most important representative body of the unit.

11 Local self-government in Poland is divided into three levels: almost 2500 municipalities, 380 counties and 16 regions. 


\section{Figure 2}

Simplified version of the Lublin operational and organization model.

\begin{tabular}{|ll|}
\hline Mayor of the City & Mayor's Department \\
\hline Deputy Mayor & Department of Investments and Development \\
\hline Deputy Mayor & Department of City Management \\
\hline Deputy Mayor & Department of Social Issues \\
\hline Deputy Mayor & Department of Culture, Sport and External Relations \\
\hline CEO & Department of Organization and Administration \\
\hline Treasurer of the City & Department of Finance \\
\hline City Council & 31 members chaired by the Chairman \\
\hline
\end{tabular}

Since the 1990s, efforts have been made to involve citizens into the decisionmaking process. Residents have a right to participate in local elections, referenda and consultations. It should be noted, however, that the level of participation and interest among residents of the city is relatively low, which reflects the general trend present in Poland. Between 1990 and 2014, voter turnout to the city council ranged from $25.5 \%$ to $41.53 \% .{ }^{12}$ Mayoral elections generate similar levels of public interest. The turnout in district council elections is even lower (see Table 2).

The authorities elected in the 2010 local elections were, however, determined to change the situation. Increasing the level of citizens' interest in city affairs as well as opening new possibilities for their involvement in the decision-making process became the priorities of the new mayor. The City authorities decided to take action in two ways. Firstly, they tried to rearrange and strengthen the institutional capacity of the city for public participation. Secondly, further steps towards greater interaction between officials from city hall and residents of Lublin have been taken (Radzik-Maruszak and Mieczkowska-Czerniak 2013).

12 Between the years 1990 and 1998, the election turnout to the Lublin city council was as follows: $1990-39.55 \%, 1994-25.5 \%, 1998-39.9 \%$. 


\section{Table 2}

Voter turnout to the Lublin city council, mayoral election and district/neighbourhood council

\begin{tabular}{|c|c|c|c|c|c|c|}
\hline \multicolumn{2}{|c|}{$\begin{array}{c}\text { City council } \\
\text { 2002-2014* }\end{array}$} & \multicolumn{3}{|c|}{ Mayoral elections 2002-2014* } & \multicolumn{2}{c|}{$\begin{array}{c}\text { District/neigh- } \\
\text { bourhood councils } \\
\text { 2006-2011** }\end{array}$} \\
\hline $\begin{array}{c}\text { Election } \\
\text { year }\end{array}$ & $\begin{array}{c}\text { Turnout } \\
(\%)\end{array}$ & $\begin{array}{c}\text { Election } \\
\text { year }\end{array}$ & $\begin{array}{c}\text { Turnout } \\
(\%) \\
\text { First round }\end{array}$ & $\begin{array}{c}\text { Turnout } \\
(\%) \\
\text { Second } \\
\text { round }\end{array}$ & $\begin{array}{c}\text { Election } \\
\text { year }\end{array}$ & $\begin{array}{c}\text { Turnout } \\
(\%)\end{array}$ \\
\hline 2002 & 33.79 & 2002 & 33.69 & 28.57 & 2006 & 4.27 \\
\hline 2006 & 41.53 & 2006 & 41.53 & 36.11 & 2009 & 3.58 \\
\hline 2010 & 39.87 & 2010 & 39.87 & 32.01 & 2011 & 6.11 \\
\hline 2014 & 41.03 & 2014 & 41.03 & - & - & - \\
\hline
\end{tabular}

*Source: PKW data. Available at http://pkw.gov.pl (last accessed 3 January 2015)

${ }^{*}$ Source: Lublin City Office web page. Available at http://um.lublin.eu/radydzielnic/index. php?t=200\&id=148828 (last accessed 3 January 2015)

\section{Institutional capacity-building}

With regard to the new institutional framework, the mayor opted for a major reorganization of the municipal office. In the structure of the mayoral Chancellery, the Department of Cooperation with NGOs and Social Participation was duly created. On the one hand, the change reflected a general trend, visible also in other Polish cities; on the other hand, however, the city hall wanted to meet the expectations of non-governmental organizations and more active groups of citizens.

Moreover, from the beginning of his incumbency, the new mayor undertook other institutional steps. An example of such activities was the establishment of "community councils". At present, the following bodies operate in the city on a regular basis: the Council for Lublin Development, the Senior Social Council, the Council for Culture of Space and the Public Benefit Council.

The Council for Lublin Development gathers knowledgeable individuals having experience in socio-economic issues. They represent the local business, universities and other organizations and communities seated in Lublin and working for its development. Thanks to the effort of many local activists, the Council managed to draw up the Lublin Development Strategy 2012-2020 (see Lublin City Office Web-Page 2012).

The Senior Social Council attends to the needs of elderly people and helps bring them back to the city's social life. Owing to the Council's initiative, the city maintains a cultural programme intended for the elderly. Currently, the Council is 
striving to identify senior-friendly spots across the city for them to spend their time actively.

The Council for Culture of Space, originating from the seasoned and informal Forum of Culture of Space, brings together city planners, architects and a large group of individuals who hold the overall city aesthetics very dear. The Council's activists not only advise the mayor on the development of spatial plans but also put forward their own ideas or projects. The Public Benefit Council of Lublin is an advisory and consultative body focusing on the city's policy on non-governmental organizations. It is made up of representatives appointed by the mayor, City Council and NGOs. The Council supports the mayor in fostering the most advantageous forms of cooperation with Lublin's many and various NGOs. This is particularly salient in Lublin which, when striving to be awarded the title of the European Capital of Culture 2016 (the city made it to the final stage of the contest, i.e. was short-listed), witnessed an unprecedented revival and mobilization of the public. Non-governmental organizations led the way in producing ideas and projects, and culture became the driving force behind the city's development (Lublin City of Inspiration, 2013). The bodies in question are in an advisory capacity and attract groups involved in a particular area. Although the council teams engage in heated disputes when discussing vital local issues, they often arrive at valuable and workable solutions. The councils are partnerships of a kind that do community work for the city and seek to raise its level of development (Radzik-Maruszak and Mieczkowska-Czerniak 2013).

\section{Participatory budgeting and service provision}

In addition, Lublin is among the cities in Poland that are actively interested in the idea of participatory budgeting. In 2011 the city decided to maintain quasi "participatory budgeting" in their districts/neighbourhoods. For four years, each of the 27 districts has maintained its own budget expended on projects in its area. The councils have about PLN 110,000 (around 26,000 Euro) at their disposal. These resources are mostly spent on the upgrading of minor local infrastructure, such as parking bays and playgrounds, but also on expanding the cultural offer, etc. However, with regard to "traditional" participatory budgeting, the implemented solution is distinguished by the fact that resource allocation is mainly determined not by all district residents, but rather by the district council.

Based on that experience, the municipal authorities decided to join the "SelfGovernment Activity Project" (Pol. Projekt Aktywności Samorzadowej - PAS) in 2011. The project has a pilot character and is financed by the European Social Fund (Measure 5.2 Strengthening the potential of local-government administration, Priority V Good Governance, Human Capital Operational Programme 2007-2013). Apart from Lublin, the PAS has been running since February 2011 in six other localgovernment units of the Lubelskie and Podkarpackie Regions; the city is, however, the largest participating unit. The partner to the aforesaid local-government units 
involved in the project is the Foundation for Managerial Initiatives (Foundation for Managerial Initiatives 2013).

The main goal of the project is to improve the process of monitoring the delivery of local services, although PAS focuses also on improving the quality of services by establishing partner relations between citizens and local authorities. The innovative aspect of the project lies in treating citizens and local organizations not as subjects of the local politics but rather as partners in the governance process. The core idea of the PAS is to build a network of interactions between local communities and authorities and to empower the people to have their say in how the services are delivered. The whole project is scheduled to be finished in January 2015. At present, it has entered its fourth phase (Radzik-Maruszak and Mieczkowska-Czerniak 2013; Foundation for Managerial Initiatives 2013).

Finally, in 2013 city authorities decided to introduce "real" participatory budgeting in 2014. The residents of Lublin reported 333 projects, 233 of which were considered for possible implementation by city hall. Voting on the projects took place in the fall of 2014; 30 projects were selected for realization (Lublin Office City Web-Page 2014).

\section{Improvements in two-way communication}

Despite the described institutional reforms, another goal of the city hall as well as in the case of Tampere was to improve the communication and to increase the level of interactions between its officers and residents. Up to now the following actions have been taken.

Firstly, the city decided to introduce the "Social Dialogue Box" in October 2011 (Social Dialogue Box, 2014). After going to www.dialog.lublin.eu, anyone can quickly register a request and a visit at the Lublin Municipal Office. However, the Social Dialogue is not only aimed to facilitate online communication. Anyone who prefers the traditional way can submit their idea or issue a printed form and drop it into purpose-made boxes at the Resident Service Bureau. In almost three years, the office collected about 2798 messages concerning the different areas of local government's activity (Lublin City Office Web-Page 2014). The issues raised by the residents were forwarded directly to the competent organizational units within the Municipal Office for implementation. Some were purely informative (RadzikMaruszak and Mieczkowska-Czerniak 2013).

Secondly, in September 2012 city hall launched a service called "Let's Fix It" (Pol. Naprawny to; Naprawmy To 2014), inspired by the British "Fix My Street" mechanism (Fix My Street: http://www.fixmystreet.com) and the American portal "Seeclickfix" (Report neighborhood issues and see them get fixed: http://seeclickfix.com). The primary function of the service is to map and report the problems and issues that require adjustment in public space, inter alia in infrastructure (e.g. road holes, broken traffic lights), public cleanliness (e.g. garbage), security (e.g. not 
enough clear stripes on high-risk zebra crossings, missing or inadequate light in potentially dangerous areas) or malfunctioning of public services (such as garbage collection). Citizens can easily report these issues through a website or by means of an application on their mobile devices. Each "entry" is logged in the system, and the message is transmitted to the city's public institutions responsible for a particular issue. In this way, the service can be used as a channel for two-way communication between city authorities and its residents. Until September 2014 some 4637 reported cases have been fixed (Naprawmy To 2014). Moreover, it should be noted that currently Lublin is the only city in Poland running such a service. Other cities ${ }^{13}$ withdrew from the project, due to the extensive organizational difficulties and demands that the portal entails.

City authorities also plan new projects. By the end of 2014 a smart phone application providing faster public consultation is scheduled to be launched. The operation of a local initiative is scheduled to be extended in 2015. This tool is considered to be a natural supplement to the participatory budgeting through which residents will be able to submit project proposals aimed at the improvement of the quality of life in the neighbourhoods (Lublin City Office Web-Page 2014).

\section{Lessons from Lublin}

During interviews city-hall officials pointed out both the strengths and the weaknesses of the described institutions and tools of public participation. The Chair of the Department of Cooperation with NGOs and Social Participation identifies the following three core issues:

First, in his opinion, the projects that have been developed in consultation with the residents of the city are much better than those developed independently by the city authorities. Therefore, the early consultations are significantly important. Second, the broader citizen involvement into the decision-making process results in mitigation of political frictions. Parties are more likely to accept the proposals and projects when they come from the residents. Finally, the activated mechanisms have the value-added effect in the sense that residents feel they have a bigger say and their opinion really matters.

Nevertheless, citizens' wider participation also causes problems. First, some residents do not use the available mechanisms and tools in a proper way. In the case of Lublin, the operation of the service "Let's Fix It" raises significant problems. One resident reported numerous instances of service malfunction, as manifested by the frequent unavailability of the website (such as time-outs). Second, experience has shown that during public consultation, the most active residents are those dissatisfied. Therefore, decisions made by city hall on the ground of their views are quite

13 For example, Poznań and Torun. 
often met with subsequent criticism from the rest of the citizens. Third, involving people into the decision-making process significantly complicates and prolongs it. As one of the interviewees pointed out:

Entering into a dialogue with the people requires different planning and organization of work. It should be a part of the city procedures. However, in reality we make many decisions at the very last moment and therefore taking residents' opinion into account is difficult.

\section{(Officer 1, 2013 Lublin)}

In addition, new opportunities of participation provoke tensions between residents, councillors and city hall. Interestingly, city as well as district/neighbourhood councillors are rather often dissatisfied with the rapprochement between residents and city authorities. One of the interviewees describes the situation in the following way:

According to a part of the councillors, the citizens' involvement and their direct relations with city hall constitute an open attack on local democracy. On the one hand, councillors are upset and disappointed by these interactions; on the other hand, they do not know how to talk to the people.

\section{(Officer 3, 2013 Lublin)}

Moreover, during the conducted interviews city officers emphasized councillors' ignorance about the issue of public participation, its regulations and mechanisms. Nevertheless, conducted interviews reveal differences between officials, as well. Citizen engagement has the strongest support among the top officers, who deal with general issues; the street-level bureaucrats, who work directly with the people and are responsible for the translation of the new policy into practice, are less enthusiastic.

Finally, the interviews conducted for the purpose of the current research project revealed yet another interesting issue. Some local officers openly admit that the implementation of particular participatory tools, e.g. participatory budgeting, is rather a political decision through which city authorities are eager to gain votes in the upcoming 2014 local elections than a real interest in closer cooperation with citizens at large.

\section{Conclusion and discussion}

Citizen participation in the context of modern local governance has been thoroughly studied by scholars, and its tools have been applied by practitioners since the 1990s. Vast scholarly literature on this topic recognizes both advantages and disadvantages of these practices. The purpose of our article was, first, to compare 
different approaches in applying the participative framework (a set of participative tools) in two democratic local-government systems on the basis of document analysis. Second, based on the in-depth interviews, we intended to find out what the pros and cons of applied frameworks are, as perceived by the main carriers of these activities - municipal civil servants.

The document analysis has led us to the following conclusions:

The city of Lublin pays considerable attention to providing the residents of Lublin with a wide range of participative tools for citizen involvement in the municipal decision-making process. In contrast, the Tampere model provides only a handful of such tools. At the same time, however, it seems that the Tampere tools have been deliberately organized in narrow channels in order to gather more focused and theme-specific information for making "better", more rational and majority-accepted decisions within the framework of representative democracy. At this point, one can also conclude that, in comparison to Lublin, Tampere seems to be already in the second - more institutionalized or hierarchal - stage of citizen participation.

Another important difference between the Lublin and Tampere approaches to civic participation is that Polish politicians seem to have more official tools for direct interaction with citizens. In the Tampere case, this interaction, excluding informal meetings, email correspondence or phone conversations with citizens, or political party membership, is limited only to those $4-5$ relatively big residents' nights' meetings, while more direct interaction is left between civil servants and citizens. What is more, in the case of Tampere the applied tools are part of the city model, whereas in Lublin some of them, e.g. participatory budgeting, are used as a result of "participatory fashion" - visible also in other cities and of interest to particular politicians.

The interviews allow us to formulate the following assumptions:

In both cities, local officials indicate similar advantages of greater citizen engagement. First, it undoubtedly bridges the gap between politicians, administrators and citizens, builds the "we spirit" as well as increasing acceptance for decisions made by city halls. Some civil servants are able to acknowledge directly that if the policy proposals are presented to the citizens in the early stage of their development, it is easier to obtain higher citizen acceptance and commitment to the later-made decisions. Second, in Tampere as well as in Lublin direct citizen involvement also constitutes a kind of response to the shortcomings of traditional representative democracy. Finnish and Polish local officials admit, however, that wider and more direct interactions with citizens bring certain challenges and have some disadvantages. The interviewees point out inter alia the necessity of preparing a new operational framework. In Tampere the main problem creates a plurality and quality of information coming from citizens. Local officials complain about an easiness to sink into the sea of non-relevant comments, highly individualistic demands, lack of common sense, duplicity of issues and unfeasible, naive or utopians expectations. In turn in 
Lublin a significant challenge is the necessity of planning in advance, the fact that decisions cannot be made at the very last moment anymore. In addition, officials in Tampere highlight the lack of equal representation among citizens who take part in the decision-making process; there are always groups that remain unheard. In Lublin, an important issue are the tensions that arise between councillors afraid of losing their position, administrators engaged in creating the new framework and demanding residents.

In conclusion, it should be, however, also emphasised that quite often the inconsistencies between the established participatory institutions and the practical way they operate in can be witnessed. In other words, those who provide and prepare participative tools are frequently unsatisfied with the outcome of their operation. One solution for this inconsistency is to change either the tools or the expectations about the outcome. Another more concrete answer to the problem is to change the overall public discourse from "costumers/consumers/users" (typical of NPM and visible in Finland) to "citizens", then the residents might be more eager to act as agents who are active in constructing political issues and are able to focus more on the common goods and predict consequences of the activity to the community as a whole. Consequently, it can be expected that civil servants would have to read or hear fewer"utopian and unfeasible" suggestions for policy improvement.

\section{Acknowledgement}

We would like to thank all our respondents from the City of Tampere and the City of Lublin who were willing to find time and share their opinions about the studied issue, as well as to our colleagues and friends who commented on this paper.

\section{References}

Act of 11 October 1991 on Local Referendum, Journal of Law 2000(88), Item 985.

Airaksinen, Jenni and Arto Haveri. 2012. "How do Local Governments Change? Variations in Time and Place for Conflicts in Different Reforms." Kunnallistieteellinen Aikakauskirja 4, 301-312.

Alvari. 2011. Available at http://www.tampere.fi/material/attachments/a/unnamed_10926/alvariesite2012.pdf (last accessed 30.01.2015).

Bátorová, Michaela. 2012. Changing Decision-Making Power of Municipal Leaders: Comparative Experiences from Finnish, Spanish and Slovak Local Governments. PhD dissertation, University of Tampere.

Bevir, Mark. 2009. Key Concepts in Governance. Thousands Oaks, California: SAGE. 
Bevir, Mark. 2011. The SAGE Handbook of Governance. Thousands Oaks, California: SAGE. Campbell, Adrian and Coulson Andrew. 2006. "Into the Mainstream: Local Democracy in Central and Eastern Europe." Local Government Studies 32(5), 543-561.

City of Tampere. 2014. "City of Tampere: The Operational Model and Organisation." Available at http://www.tampere.fi/material/attachments/o/5oFNHQlDo/ DK_TRE_TOIMII_english_netti.pdf ().

City of Tampere. 2011, 2013. "Vaikuttamiskanavat." Available at http://www.tampere.fi/tampereinfo/osallistuminen/vaikuttamiskanavat.html (last accessed 30.01.2015).

City of Tampere. 2007. "City of Tampere: The Operational Model and Organisation." Available at http://www.tampere.fi/material/attachments/o/5oFNHQlDo/ tretoimiiesite2011eng.pdf (last accessed 30.01.2015).

Dahl, Robert A. 1956. A Preface to Democratic Theory. Chicago, Ill.: The University of Chicago Press.

Denters, Bas and Lawrence E. Rose. 2005. Comparing Local Governance: Trends and Developments. Houndmills, Basingstoke Hampshire \& 175 Fifth Avenue, New York N. Y. 10010, Palgrave Macmillan.

Flinders, Mathew and David S. Moon. 2011. "The Problem of Letting Go: The 'Big Society', Accountable Governance and 'the Curse of the Decentralizing Ministers"' Local Economy 26(8), 652-662.

Foundation for Managerial Initiatives. 2013. Available at http://fim.org.pl (last accessed 15.02.2015).

Haveri, Arto, Inga Nyholm, Asbjørn Røiseland and Irene Vabo. 2009. "Governing Collaboration: Practices of Meta-Governance in Finnish and Norwegian Local Governments." Local Government Studies 35(5), 539-556.

Häikiö, Liisa. 2010. "The Diversity of Citizenship and Democracy in Local Public Management Reform." Public Management Review 12(3), 363-384.

Häikiö, Liisa. 2007. "Expertise, Representation and the Common Good: Grounds for Legitimacy in the Urban Governance Network." Local Government Studies 44(11), 2147-2162.

Irvin, Renée A. and John Stansbury. 2004. "Citizen Participation in Decision Making: Is It Worth the Effort?" Public Administration Review 64(1), 55-65.

Jessop, Bob. 2013. “Metagovernance." In Mark Bevir (ed.).The Sage Handbook of Governance. London: SAGE Publications Ltd, 106-123.

John, Peter. 2001. Local Governance in Western Europe. London: SAGE Publication Ltd. 
Klijn, Erik Hans. 2008. “Governance and Governance Networks in Europe." Public Management Review 10(4), 505-525.

Levi-Faur, David. 2012. The Oxford Handbook of Governance. Oxford: Oxford University Press.

Loughlin, John, Frank Hendriks and Anders Lidström (eds). 2010. The Oxford Handbook of Local and Regional Democracy in Europe. Oxford: Oxford University Press.

Lublin City of Inspiration. 2013. Available at http://kultura.lublin.eu (last accessed 15.02.2015).

Lublin City Office Web-Page. 2012, 2013, 2014. Available at http://www.um.lublin. eu (last accessed 15.02.2015.

McLaverty, Peter. 2011. "Participation.” In Mark Bevir (ed.). The Sage Handbook of Governance. Thousand Oaks, California: SAGE Publication Ltd, 402-418.

Mouritzen, Paul E. and James H. Svara. 2002. Leadership at the Apex: Politicians and Administrators in Western Local Governments. Pittsburgh: University of Pittsburgh Press.

Naprawmy To. 2013. Available at http://www.lublin.naprawmyto.pl (last accessed 15.02.2015).

Nurminen, Tiina. 2012. ASUKASILTOJEN ARVIOINTI. Available at http:// www.tampere.fi/material/attachments/a/6E6dhhvQS/asukasillat_raportti_040912.pdf (last accessed 20.12.2014).

OBOP. 1999. "Ocena reform społecznych.” Available at http://tnsglobal.pl/archiv_ files/090-99.pdf (last accessed 30.04. 2014).

Osborne, David and Ted Gaebler. 1993. Reinventing Government: How the Entrepreneurial Spirit is Transforming the Public Sector. New York: Plume.

Pawłowska, Agnieszka. 2007. "Governance: Possible or Desirable in Democracies under Transformation?" TEKA: Commission of Political Science and International Affairs 2, 161-169.

Piasecki, Andrzej K.2006. Menadżer i polityk. Wójt, burmistrz, prezydent miasta, Kraków: Profesjas, 1-389.

PKW. 2013. Available at http://pkw.gov.pl (last accessed 15.02.2015).

Radzik-Maruszak, Katarzyna and Katarzyna Mieczkowska-Czerniak. 2013. "From Indifference to Protest: Citizens' Activity at the Local Level in Poland." Annales UMCS Sectio K 20, 151-169.

Rhodes, Rod A. W. 1996. "The new governance: Governing without Government", Political Studies 44, 652-667. 
Rhodes, Rod A. W. 1997. Understanding Governance: Policy Networks, Governance, Reflexivity and Accountability. Buckingham: Open University Press.

Sandberg Siv. 2004. Local Government in Finland. Available at http://64.233.183.104/ search?q=cache:JfvOoQfrZzAJ:web.abo.fi/fak/esf/lindman/offentlig_forvaltning/word/Local\%2520government\%2520in\%2520Finland\%2520\%2520Siv\%2520Sandberg.doc+Siv+Sandberg+Finnish+Local+GOvernmen $\mathrm{t} \& \mathrm{hl}=\mathrm{sk} \& \mathrm{ct}=\mathrm{clnk} \& \mathrm{~cd}=1 \& \mathrm{gl}=\mathrm{sk}$ (last accessed 15.01.2015).

Sartori, Giovanni. 1987. The Theory of Democracy Revisited. Chatham: Chatham House Publishers.

Simon, Herbert A. 1997. Administrative Behaviour: A Study of Decision-Making Processes in Administrative Organizations. $4^{\text {th }}$ edn. New York: Simon \& Schuster, Inc.

Social Dialogue Box. 2014. Available at www.dialog.lublin.eu (last accessed 15.05.2015).

Statistic Finland. 2015. Available at http://www.stat.fi/index_en.html (last accessed 22.06.2015).

Stoker, Gerry. 2011. "Was Local Governance such a Good Idea? A Global Comparative Perspective." Public Administration 89(1), 15-31.

Swianiewicz, Paweł. 2011. "Poland: Europeanization of Subnational Governments." In John Loughlin, Frank Hendriks and Anders Lidström (eds), The Oxford Handbook of Local and Regional Democracy in Europe. Oxford, Oxford University Press, 480-504.

Swianiewicz, Paweł. 2002. "Modele samorządutery torialnego w państwach Europy Zachodnieji Środkowowschodniej: Próba generalizacji." Studia Regionalne $i$ Lokalne 4(10),53.

Swianiewicz, Paweł, Andrzej Mielczarek and Urszula Klimska. 2006. "Uneven Partnerships: Polish City leaders in Search of Local Governance." In Hubert Heinelt, David Sweeting and Panagiotis Getimis (eds). Legitimacy and Urban Governance: A Cross-National Comparative Study. Abingdon: Routledge, $114-130$.

Tampereenkaupunki: kuntademokratiayksikkö. 2011. “Alue-Alvari-Opas." Available at http://www.tampere.fi/material/attachments/a/5wU7tgd7k/alue_alvari_opas.pdf (last accessed 15.01.2015).

Torfing, Jacob, B. Guy Peters, Jon Pierre and Eva Sørensen. 2012. Interactive Governance: Advancing the Paradigm. Oxford: Oxford University Press.

Valma forum. 2013. Available at http://valma.tampere.fi/selaus (last accessed 15.01.2015). 